\title{
Comparative Effects of Telmisartan versus Valsartan on serum Leptin level, in hypertensive type 2 diabetes mellitus patients
}

\author{
Najlaa Saadi Ismael, Fathel Abaas Al-hamamy \\ Department of Pharmacology, Mosul College of Medicine, University of Mosul, Iraq \\ Correspondence: dr.najlaasaadi@yahoo.com
}

$\begin{array}{lll} & \frac{\text { Received }}{16.12 .2013} & \frac{\text { Accepted }}{22.1 .2014}\end{array}$

Objective: The aim of this study was to compare the effects of telmisartan and valsartan on blood pressure and serum leptin in hypertensive type 2 diabetes Mellitus patients.

Study design: A randomized control comparative clinical trial with open label design.

Study period: From 1st February, 2012 to 30th March, 2013.

Patients and method: Eighty eight type 2 diabetic hypertensive patients were randomly assigned to received either telmisartan $(n=46)$ or valsartan $(n=42)$ with body mass index (BMI) $31.52 \pm 4.73 \mathrm{~kg} / \mathrm{m}^{2}, 30.39 \pm 3.95 \mathrm{~kg} / \mathrm{m}^{2}$ respectivly. Forty one diabetic normotensive patients $(n=41)$, age, sex, BMI, duration of diabetic disease, duration of diabetic treatment matched to the diabetic hypertensive patients groups were kept as control group. blood pressure (BP), leptin levels were measured at baseline and after 2 months of treatment.

Results: The study showed a significant higher systolic blood pressure (SBP), diastolic blood pressure (DBP) and serum leptin in the diabetic hypertensive patients before starting therapy as compared with the diabetic normotensive patients. Both telmisartan and valsartan significantly reduced serum leptin and BP. More reduction in DBP seen with valsartan than with telmisartan.

Conclusion: Monotherapy with telmisartan and valsartan produce a beneficial reduction effects on BP and reduce leptin level. The improvement of leptin sensitivity may play a role directly or indirectly in the induction of hypertension control.

Key words: Leptin, telmisartan, valsartan, blood pressure, type 2 Diabetes Mellitus

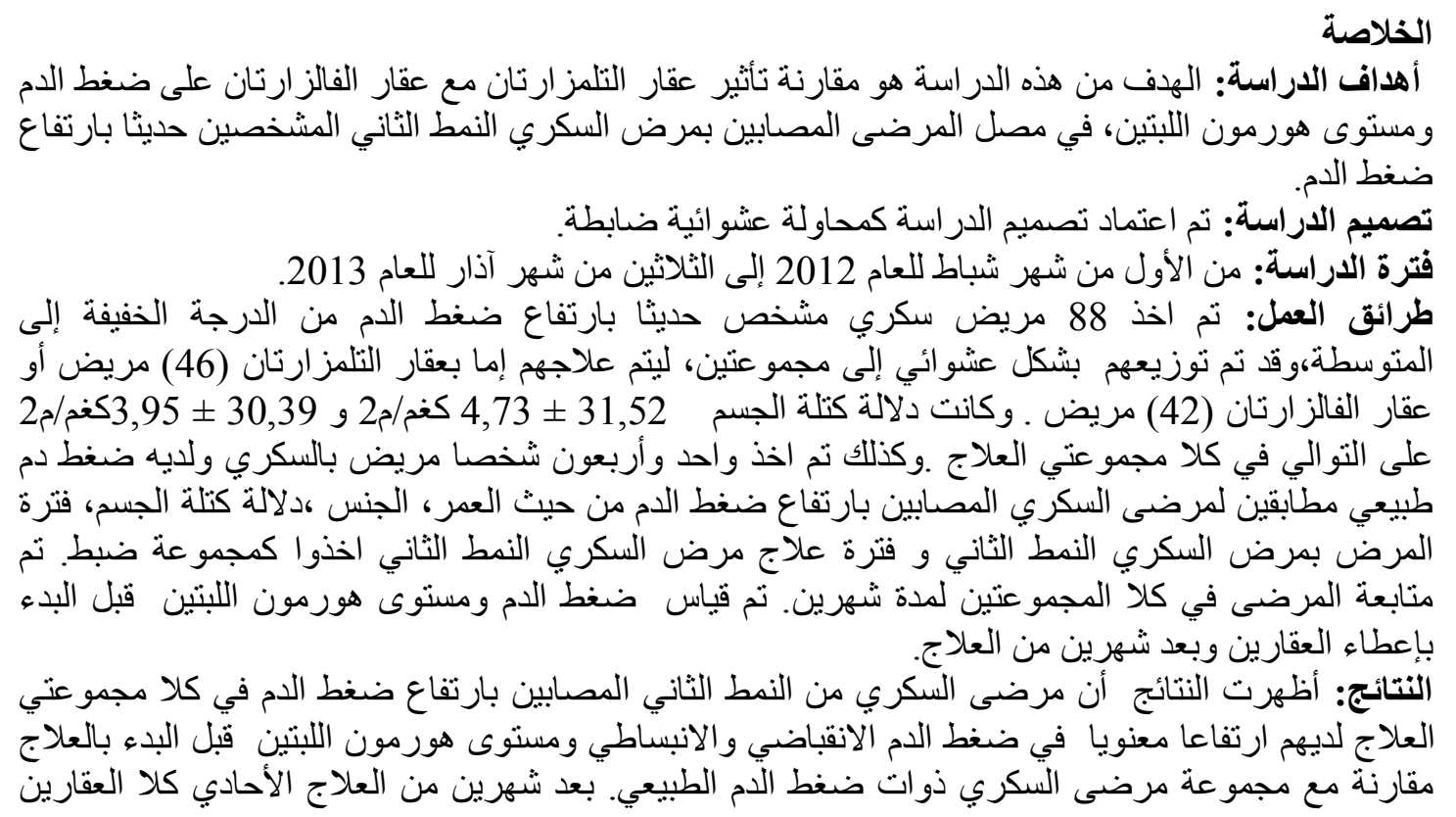




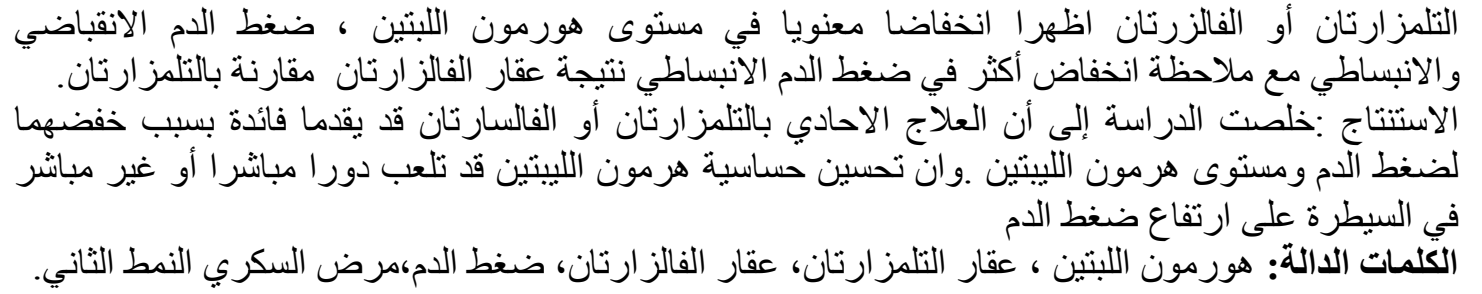

$\mathrm{L}$ eptin, a peptide hormone comprising 167 amino acids, is mainly released by adipocyte $^{1}$, and its expression is proportional to size of adipocytes and to amount of adipose depots ${ }^{2}$.

Although leptin reduces food intake and body weight, obesity is characterized by high plasma leptin levels. In this regard, several studies have shown that attenuated leptin signaling is present in this metabolic disorder. This leptin resistance would explain why high leptin levels fail to induce the expected decreasing effects on feeding and body weight that would mitigate obesity. Several factors have been shown to mediate leptin resistance at the central level: impaired leptin transport in the bloodbrain barrier, endoplasmic reticulum stress, and impaired leptin signaling, leptin receptor internalization, receptor mutations and post-receptor signaling defects. Furthermore, the active hormone may be reduced by binding proteins or soluble receptors 5 .

Apparently, many patients are resistant to leptin satiety and weight reducing actions, where as sympathoexcitatory actions are preserved, a phenomenon referred to as selective leptin resistance ${ }^{6}$, this phenomenon might explain in part how hyperleptinemia could be accompanied by obesity (partial loss of appetite and metabolic actions of leptin) but still contribute to sympathetic over activity and hypertensive because of preservation of the sympathetic actions of leptin to some organs involved in BP regulation ${ }^{7}$.
Leptin is shown to be related to metabolic, inflammatory, and haemostatic factors involved in hypertension development ${ }^{8}$, chronic hyperleptinemia has been shown to enhance sympathetic nervous activity and reduces nitric oxide dependent vasodilation and natriuresis stimulates renin-angiotensin which may affect BP level in humans ${ }^{9}$.

Leptin has peripheral actions to stimulate vascular inflammation, oxidative stress, and vascular smooth muscle hypertrophy that may contribute to pathogenesis of T2DM, hypertension, Angiotensin II (Ang II) increases leptin synthesis in cultured adipose cells. Adipose tissue-derived Ang II and leptin may act synergistically to promote obesityrelated hypertension ${ }^{10}$.

Insufficient suppression of the renin angiotensin aldosterone system (RAAS) has been implicated in the development of obesity-related high arterial pressure, and is linked with insulin resistance(IR) and $\mathrm{T}_{2} \mathrm{DM}^{11}$. Angiotensin receptor blockers (ARBs) are regarded as first-line treatments for T2DM with hypertension ${ }^{12}$.

The aim of the present study is to evaluate the effect of telmsartan and valsartan on serum leptin level in hypertensive type 2 diabetes Mellitus patients.

\section{Patients and methods}

This is a randomized control comparative clinical trial with open label design study which was conducted in the Department of Pharmacology, College of Medicine, 
Univrsity of Mosul and Al-Wafa Diabetic Center in Mosul from 1st February, 2012 to 30th March, 2013. Eighty eight (88) hypertensive type 2 diabetic patients participated in this study. Forty six patients (21 male, 25 female) whose ages ranged between 41 and 70 year $(54.41 \pm 7.19$ year), were kept on telmisartan $80 \mathrm{mg}$. (Telmi ${ }^{\circledR}$, Diamond Pharma, Syria), once daily after breakfast for two month. The remaining forty two patients (20 male, 22 female) whose ages ranges from 40 and 67 year with $(53.02 \pm 6.95$ year), were received valsartan $80 \mathrm{mg}$ (Diostar $^{\circledR}$, Pharma International Co.Amman-Jordan) once daily for 2 months.

The patients have mild to moderate hypertension were either newly diagnosed or already diagnosed with hypertension, at some point used antihypertensive, but for various reasons, not currently taking drugs for hypertension. Patients with Type1 diabetes mellitus, Patients treated with thiazolidinediones, insulin, statins and smokers were excluded from the study. Forty one diabetic normotensive patients age, sex, BMI, duration of diabetic disease, duration of diabetic treatment matched to the diabetic hypertensive patients groups were kept as a control group. BP, leptin levels were measured at baseline (before treatment) and after 2 months of treatment .

Blood pressure was measured after 30 minutes rest in the sitting position. Mean values of 3 consecutive measurements, separated by about 1520 minutes, were calculated and used for the analyses. The diabetic patients were classified as hypertensive if their systolic blood pressure $\geq 130 \mathrm{mmHg}$, diastolic blood pressure $\geq 80 \mathrm{mmHg}$ or both $^{13}$.

Five $\mathrm{ml}$ of venous blood samples were collected from each patient after at least 12 hours fasting. Serum leptin was measured using the GenWay human leptin ELISA kit (USA) which is based on standard sandwich enzyme linked immuno-sorbent assay $(\text { ELISA) })^{14}$.

\section{Statistical data analysis}

The data obtained in the current study has analyzed using Statistical package for social sciences (SPSS) program (version17), ANOVA method were used to analyze the comparison between the groups. Standard statistical methods were used to determine the mean and standard deviation $(\mathrm{M} \pm \mathrm{SD})$. Unpaired Student $t$ test was used to compare the results of various biochemical parameters of diabetic hypertensive patients with the comparative group. Paired Student $t$ test was used to compare the results of various biochemical parameters in diabetic hypertensive patients before and after therapy in each group. Pvalue $\leq 0.05$ was considered to be statistically significant.

\section{Results}

The demographic characteristic and mean baseline data of all studied groups were shown in (Table1) the patients were relatively obese, BMI $\geq$ $30 \mathrm{~kg} / \mathrm{m}^{2}$ ). There were non-significant differences regarding the sex, age, BMI, waist circumference, duration of diabetic disease and duration of diabetic treatment among the study groups. 
Table 1. Characteristics of the studied patients

\begin{tabular}{|l|l|l|l|l|}
\hline \multicolumn{1}{|c|}{ Groups } & \multicolumn{3}{c|}{ Mean \pm SD } \\
\cline { 2 - 5 } & $\begin{array}{l}\text { Diabetic } \\
\text { normotensive } \\
(\mathrm{n}=41)\end{array}$ & $\begin{array}{l}\text { Telmisartan } \\
\text { Group }(\mathrm{n}=46)\end{array}$ & $\begin{array}{l}\text { Valsartan } \\
\text { Group (n=42) }\end{array}$ & $\begin{array}{l}p- \\
\text { value }\end{array}$ \\
\hline $\begin{array}{l}\text { Sex (NO, \%) } \\
\text { Male } \\
\text { Female }\end{array}$ & $\begin{array}{l}19(46.3 \%) \\
22(53.7 \%)\end{array}$ & $\begin{array}{l}21(45.7 \%) \\
25(54.3 \%)\end{array}$ & $\begin{array}{l}20(47.6 \%) \\
22(52.4 \%)\end{array}$ & $\begin{array}{l}0.98 \dagger \\
(\mathrm{NS})\end{array}$ \\
\hline Age (Years) & $52.54 \pm 7.94$ & $54.41 \pm 7.19$ & $53.02 \pm 6.95$ & $\begin{array}{l}0.44 \ddagger \\
(\mathrm{NS})\end{array}$ \\
\hline BMI (kg/m $\left.{ }^{2}\right)$ & $30.29 \pm 5.36$ & $31.52 \pm 4.73$ & $30.39 \pm 3.95$ & $\begin{array}{l}0.40 \ddagger \\
(\mathrm{NS})\end{array}$ \\
\hline $\begin{array}{l}\text { Waist circumference } \\
\text { (cm) }\end{array}$ & $104.73 \pm 9.59$ & $107.07 \pm 7.29$ & $106.43 \pm 10.34$ & $\begin{array}{l}0.48 \ddagger \\
(\mathrm{NS})\end{array}$ \\
\hline $\begin{array}{l}\text { Duration of diabetic } \\
\text { disease (Years) }\end{array}$ & $3.90 \pm 1.69$ & $3.89 \pm 2.00$ & $4.31 \pm 1.84$ & $\begin{array}{l}0.38 \ddagger \\
(\mathrm{NS})\end{array}$ \\
\hline $\begin{array}{l}\text { Duration of diabetic } \\
\text { treatment (Years) }\end{array}$ & $3.32 \pm 1.24$ & $3.01 \pm 1.57$ & $3.05 \pm 1.20$ & $\begin{array}{l}0.70 \ddagger \\
(\mathrm{NS})\end{array}$ \\
\hline \hline
\end{tabular}

$\dagger$ Chi-square test

+ One-way ANOVA test

NS: Non significant

The diabetic hypertensive patients at baseline have a significantly higher SBP, DBP than diabetic normotensive patients. the serum leptin in diabetic hypertensive at baseline is significantly higher than serum leptin in diabetic normotensive pateints (Table 2)

Table 2. Comparison SBP, DBP and serum leptin between the studied groups

\begin{tabular}{|l|l|l|l|}
\hline \multirow{2}{*}{ parameters } & $\begin{array}{l}\text { Diabetic hypertensive } \\
\text { patients N=88 }\end{array}$ & $\begin{array}{l}\text { Diabetic } \\
\text { normotensive } \\
\text { pateints N=41 }\end{array}$ & \multirow{2}{*}{ P-value } \\
\cline { 2 - 3 } & Mean \pm SD & Mean \pm SD & \\
\hline SBP $(\mathrm{mmHg})$ & $151.75 \pm 8.38$ & $118.02 \pm 4.78$ & $<0.000$ \\
\hline DBP $(\mathrm{mmHg})$ & $99.38 \pm 6.80$ & $77.73 \pm 8.06$ & $<0.000$ \\
\hline Serum leptin $(\mathrm{ng} / \mathrm{ml})$ & $16.76 \pm 7.66$ & $13.94 \pm 6.75$ & 0.05 \\
\hline
\end{tabular}

Unpaired $t$-test 
Table 3. Comparison of SBP, DBP and serum leptin between telmisartan and valsartan groups at baseline

\begin{tabular}{|l|l|l|l|}
\hline \multirow{2}{*}{ Parameters } & $\begin{array}{l}\text { Telmisartan group } \\
\mathrm{N}=46\end{array}$ & $\begin{array}{l}\text { Valsartan group } \\
\mathrm{N}=42\end{array}$ & \multirow{2}{*}{ P-value } \\
\cline { 2 - 4 } & Mean $\pm \mathrm{SD}$ & Mean $\pm \mathrm{SD}$ & \\
\hline SBP $(\mathrm{mmHg})$ & $150.52 \pm 9.21$ & $153.10 \pm 7.24$ & $0.15(\mathrm{NS})$ \\
\hline DBP $(\mathrm{mmHg})$ & $97.83 \pm 5.42$ & $101.07 \pm 7.77$ & 0.03 \\
\hline Serum leptin $(\mathrm{ng} / \mathrm{ml})$ & $17.08 \pm 8.16$ & $16.41 \pm 7.15$ & $0.68(\mathrm{NS})$ \\
\hline
\end{tabular}

Unpaired t-test

NS: Non significant

No significant difference was found between SBP and serum leptin of valsartan group and telmisartan group at baseline. Whereas, DBP showed significant differences (Table 3) .
A significant reduction of DBP, SBP and leptin level after 2 months treatment with telmisartan and valsartan (Table 4 and 5).

Table 4. SBP, DBP and serum leptin level before and after treatment with telmisartan

\begin{tabular}{|l|l|l|l|l|l|}
\hline \multicolumn{2}{|l|}{ Telmisartan } \\
\hline $\begin{array}{l}\text { parameters } \\
\text { Mean } \pm \text { SD }\end{array}$ & $\begin{array}{l}\text { Before } \\
\text { treatment }\end{array}$ & $\begin{array}{l}\text { After } \\
\text { treatment }\end{array}$ & $\begin{array}{l}\text { Mean } \\
\text { difference }\end{array}$ & $\begin{array}{l}95 \% \text { CI of } \\
\text { difference }\end{array}$ & $\begin{array}{l}\text { P- } \\
\text { value }\end{array}$ \\
\hline $\begin{array}{l}\text { SBP } \\
(\mathrm{mmHg})\end{array}$ & $150.52 \pm 9.21$ & $129.35 \pm 7.65$ & -21.17 & $18.32 \_24.03$ & $<0.000$ \\
\hline $\begin{array}{l}\text { DBP } \\
(\mathrm{mmHg})\end{array}$ & $97.83 \pm 5.42$ & $89.89 \pm 6.28$ & -7.94 & $5.94 \_9.93$ & $<0.000$ \\
\hline $\begin{array}{l}\text { Serum } \\
\text { leptin } \\
(\mathrm{ng} / \mathrm{ml})\end{array}$ & $17.08 \pm 8.16$ & $14.97 \pm 8.93$ & -2.12 & $0.05 \_4.19$ & 0.05 \\
\hline
\end{tabular}

paired $t$-test 
Table 5. SBP, DBP and serum leptin level before and after treatment with valsartan

\begin{tabular}{|l|l|l|l|l|l|}
\hline \multicolumn{7}{|l|}{ Valsartan } \\
\hline $\begin{array}{l}\text { Parameters } \\
\text { Mean } \pm \text { SD }\end{array}$ & $\begin{array}{l}\text { Before } \\
\text { treatment }\end{array}$ & $\begin{array}{l}\text { After } \\
\text { treatment }\end{array}$ & $\begin{array}{l}\text { Mean } \\
\text { difference }\end{array}$ & $\begin{array}{l}95 \% \quad \text { CI of } \\
\text { difference }\end{array}$ & P-value \\
\hline $\begin{array}{l}\text { SBP } \\
(\mathrm{mmHg})\end{array}$ & $153.10 \pm 7.24$ & $128.75 \pm 6.81$ & -24.35 & $21.90 \_26.79$ & $<0.000$ \\
\hline $\begin{array}{l}\text { DBP } \\
(\mathrm{mmHg})\end{array}$ & $101.07 \pm 7.77$ & $87.26 \pm 4.84$ & -13.81 & $11.06 \_16.56$ & $<0.000$ \\
\hline $\begin{array}{l}\text { Serum } \\
\text { leptin } \\
(\mathrm{ng} / \mathrm{ml})\end{array}$ & $16.41 \pm 7.15$ & $14.84 \pm 6.91$ & -1.57 & $-0.003 \_3.15$ & 0.05 \\
\hline
\end{tabular}

Paired t-test

Table 6. The reduction of the mean of SBP, DBP and serum leptin between telmisartan and valsartan

\begin{tabular}{|l|l|l|l|}
\hline \multirow{2}{*}{ Parameter } & \multicolumn{2}{|l|}{ Mean differences } & \multirow{2}{*}{ P-value } \\
\cline { 2 - 4 } & $\begin{array}{l}\text { Telmisartan } \\
\text { Mean } \pm \text { SE }\end{array}$ & $\begin{array}{l}\text { Valsartan } \\
\text { Mean } \pm \text { SE }\end{array}$ & \\
\hline SBP (mmHg) DBP (mmHg) & $-21.17 \pm 1.42$ & $-24.35 \pm 1.21$ & $0.10(\mathrm{NS})$ \\
\hline DBP (mmHg) & $-7.94 \pm 0.99$ & $-13.81 \pm 1.36$ & 0.001 \\
\hline Serum leptin $(\mathrm{ng} / \mathrm{ml})$ & $-2.12 \pm 1.03$ & $-1.57 \pm 0.78$ & $0.18(\mathrm{NS})$ \\
\hline
\end{tabular}

Unpaired t-test

NS: Non significant

Comparison between the reduction of the mean of SBP, DBP and serum leptin of telmisartan and valsartan showed asignificant difference only in DBP (Table 6).

\section{Discussion}

Angiotensin receptor blockers have become an important class of drugs, with clinical benefits in the treatment of hypertension in patients with diabetes $^{15}$, and all of the drugs in this class bind to the AT1receptor thereby inhibiting the multiple actions of Ang II that are mediated by that receptor, including vasoconstriction, mitogenic activity, cytokine production, reactive oxygen species formation. increases aldosterone release and sympathetic activity $^{16,17}$. Some ARBs can function as a partial agonist of peroxisome proliferator-activated receptor gamma (PPAR- $\gamma$ ) and improve carbohydrate and lipid metabolism ${ }^{17}$. Leptin and RAS mediate sympathetic activation and parasympathetic withdrawa ${ }^{16}$. Leptin showed high levels in diabetic hypertensive patients when compared with diabetic normotensive patients, and SBP, DBP were significantly 
higher in diabetic hypertensive patients when compared with diabetic normotensive. These results may be due to the sympathetic system activation throughout leptin activity, this result were in agreement with the evidence which found that chronic hyperleptinemia has been shown to enhance sympathetic nervous system activity and reduces nitric oxide dependent vasodilation and natriuresis ${ }^{18}$. Leptin stimulates reninangiotensin and sympathetic system ${ }^{19}$, natriuresis which may affect BP level in human and that a blunted effect of leptin may predispose to hypertension in human ${ }^{9}$.

At the end of the 2-month treatment period, there was a significant reductions in SBP and DBP from baseline values in both treatments. The ability of valsartan and telmisartan to reduce BP have resulted primarily from its antagonistic action on angiotensin type 1 (AT1) receptors.

The results of telmisartan and valsartan therapy on blood pressure in the present study were in agreement with many previous study(20-23). In this study valsartan significantly reduced DBB greater than telmisartan. These results suggest that the superiority of valsartan on DBP lowering effect might be related to its strength rather than to the duration of its pharmacological action .

A meta analysis study 24 showed no differences between telmisartan's BPlowering capabilities and valsartan BPlowering capabilities as monotherapy, but when combined with hydrochlorothiazide, telmisartan was more effective than valsartan.
By the end of the 2-month treatment period, the present study showed reductions in serum leptin level from baseline values, in both treatment. In the literature, both increase 25 and decrease ${ }^{26-28}$, in fasting leptin concentrations have been reported after administration of telmisartan, moreover, the lack of effect of telmisartan on circulating leptin also has been reported ${ }^{29}$. With regard valsartan reports conflicting between increase $^{28}$ or decrease serum leptin level30 or having no effect ${ }^{31}$.

Angiotensin II regulates the production of adipokines, it increases the expression and the release of proinflammatory cytokines $^{32}$, increases leptin ob gene expression and secretion33. Thus, inhibition of Ang II by ARBs might result in reduced leptin production.

Renin angiotensin system blockade by (ARBs) promotes the differentiation of adipocytes via angiotensin II type 1 receptor blocking ${ }^{10}$, and by Peroxisome proliferator-activated receptor gamma (PPAR- $\gamma$ ) activation with subset of ARBs. PPAR- $\gamma$ agonists have an anti-inflammatory role, as shown by their inhibitory effects on the production of inflammatory cytokines $^{34}$, the formation and release of adipocytokines are partly regulated via PPAR-dependent pathways ${ }^{27}$.

\section{Conclusion}

Monotherapy with telmisartan and valsartan produce a beneficial reduction effects on $\mathrm{BP}$ and reduce leptin level. The improvement of leptin sensitivity may play a role directly or indirectly in the induction of hypertension control. 


\section{References}

1. Mantzoros CS, Magkos F, Brinkoetter $M$, et al. Leptin in human physiology and pathophysiology. Am J Physiol Endocrinol and Metab 2011;301:E567-E584.

2. Slavov EP, Dzhelebov PV. Basic endocrine products of adipose tissue-a review. Bulg J Vet Med 2010;13:199210.

3. Morris DL, Rui L. Recent advances in understanding leptin signaling and leptin resistance. Am J Physiol Endocrinol Metab. 2009;297(6):E1247-59.

4. Ozcan L, Ergin AS, Allen LU, et al. Endoplasmic reticulum stress plays a central role in development of leptin resistance. Cell Metab 2009;9:35-51.

5. Hahn S, Haselhorst U, Quadbeck B, et al. Decreased soluble leptin receptor levels in women with polycystic ovary syndrome.Eur J Endocrinol 2006;154:287-294.

6. Andrey C, Goncalves DC, Tank J, et al. Diabetic hypertensive. leptin receptor-deficient $\mathrm{db} / \mathrm{db}$ mice develop cardioregulatory autonomic dysfunction. Hypertension 2009; 53:387-392.

7. Rahmouni K, Haynes WG. Leptin and the Cardiovascular System. rphr.endojournals.org by on June 9,2013.

8. Shankar A, Xiao J. Positive relationship between plasma leptin level and hypertension. Hypertension 2010;56(4):623-8.

9. Khokhar KK, Sharda Sidhu S, Kaur G. Correlation between leptin level and hypertension in normal and obese pre-and postmenopausal women. Eur J Endocrinol 2010;163:873-878.
10. Umeda M, Kanda T, Murakami M. Effects of angiotensin II receptor antagonists on insulin resistance syndrome and leptin in sucrose-fed spontaneously hypertensive rats. Hypertens Res 2003:26:485-492.

11. Rahmouni K, Correia ML, Haynes WG, et al. Obesity-associated hypertension: new insights into mechanisms. Hypertension 2005;45(1):9-14.

12. Nakayama $S$, Watada $H$, Mita $T$, et al. Comparison of effects of olmesartan and Telmisartan on blood pressure and metabolic parameters in Japanese early-stage type-2 diabetes with hypertension. Hypertens Res 2008;31(1):7-13.

13. ADA. Standards of medical care in diabetes. Diabetes Care 2011;34:S11S61.

14. Masuzaki H, Ogawa $Y$, Sagawa N, et al. Non adipose tissue production of Leptin: Leptin as a novel placentaderived hormone in humans. Nat Med 1997;3(9):1029-1033.

15. Siragy HM. A current evaluation of the safety of angiotensin receptor blockers and direct renin inhibitors. Vasc Health Risk Manag 2011; 7:297313.

16. Taylor AA, Siragy H, Nesbitt S. Angiotensin receptor blockers: pharmacology, efficacy and safety. J Clin Hypertens (Greenwich) 2011; 13:677-686.

17. Cernes R, Mashavi M, Zimlichman R. Differential clinical profile of candesartan compared to other angiotensin receptor blockers. Vasc Health Risk Manag 2011;7:74959. 
18. Beltowski J. Role of leptin in blood pressure regulation and arterial hypertension. J Hypertens 2006; 24:789-801.

19. Stenvinkel P. Leptin and blood pressure - is there a link?. Nephrol, Dial, Transplant 2000;15:1115-1117.

20. Wohl P, Krusinová E, Hill M, et al. Effect of telmisartan on selected adipokines, insulin sensitivity, and substrate utilization during insulinstimulated conditions in patients with metabolic syndrome and impaired fasting glucose. Eur J Endocrinol 2010;163(4):573-83.

21. Barutcuoglu B, Parildar z, Mutaf MI, et al . Effect of telmisartan on vascular endothelium in hypertensive and type 2 diabetic hypertensive patients. Turk J Med Sci 2010; 40(2):239-248.

22. Nixon RM, Müller E, Lowy A, et al. Valsartan vs. Other angiotensin II. receptor blockers in the treatment of hypertension: a meta-analytical approach. Int J Clin Pract 2009; 63(5):766-75.

23. Ridker PM, Danielson E, Rifai N, et al. Valsartan, blood pressure reduction, and c-reactive protein primary report of the Val-MARC trial. Hypertension 2006;48:73-79.

24. Zheng $Z$, Lin S, Shi $H$, et al. A Systematic review and meta-analysis of telmisartan vs valsartan in the management of essential hypertension. Clin Hypertens (Greenwich) 2010; 12:414-421.

25. Usui I, Fujisaka S, Yamazaki K, et al. Telmisartan reduced blood pressure and HOMA-IR with increasing plasma leptin level in hypertensive and type 2 diabetic patients. Diabetes Res Clin Pract 2007;77:210-214.

26. Derosa G, Cicero AF, Angelo AD, et al. Telmisartan and irbesartan therapy in type 2 diabetic patients treated with rosiglitazone: effects on insulin-resistance, leptin and tumor necrosis factor-alpha. Hypertens Res 2006; 29:849-856.

27. De Luis D, Conde R, Sagrado G, et al. Effects of telmisartan vs olmesartan on metabolic parameters, insulin resistance and adipocytokines in hypertensive obese patients. Nutr Hosp 2010;25(2):275-279.

28. Younis F, Stern N, Limor R, et al. Telmisartan ameliorates hyperglycemia and metabolic profile in non obese Cohen-Rosenthal diabetic hypertensive rats via peroxisome proliferator activator receptor-gamma activation. Metab 2010;59(8):1200-9.

29. Nakamura $T$, Kawachi $K$, Saito $Y$, et al. Effects of ARB or ACE-inhibitor administration on plasma levels of aldosterone and adiponectin in hypertension. Int Heart J 2009;50:501512.

30. Imran SA, Bown RE, Wilkinson M. Tissue-specific effects of Valsartan on rstn and fiaf gene expression in the ob/ob mouse. Diab Vasc Dis Res 2010;7(3):231-238.

31. Goossens GH, Moors CC, Van der zijl NJ, et al. valsartan improves adipose tissue function in humans with impaired glucose metabolism: a randomized placebo-controlled doubleblind trial. PLoS One 2012; 7(6):e39930.

32. Pfeffer MA, Swedberg K, Granger $\mathrm{CB}$, et al. Effects of candesartan on mortality and morbidity in patients 
with chronic heart failure: the CHARM

- Overall programme. Lancet 2003; 6(362):759-766.

33. Dahlof B, Devereux RB, Kjeldsen $\mathrm{SE}$, et al. Cardiovascular morbidity and mortality in the Losartan Intervention For Endpoint reduction in hypertension study (LIFE): a randomized trial against atenolol. Lancet 2002;359:9951003.
34. Iwashita M, Sakoda H, Kushiyama A, et al. Valsartan, independently of AT1 receptor or PPAR- $\gamma$, suppresses LPS-induced macrophage activation and improves insulin resistance in cocultured adipocytes. Am J Physiol Endocrinol Metab 2012;302:E286E296. 